\title{
Religiosity And Investment Risk Taking
}

\author{
Wida Purwidianti ${ }^{1}$, Akhmad Darmawan ${ }^{2}$, Tri Septin Mujirahayu ${ }^{3}$ \\ \{widapurwidianti@ump.ac.id ${ }^{1}$,akhmaddarmawan@ump.ac.id²,triseptinmujirahayu@ump.ac.id ${ }^{3}$ \} \\ Universitas Muhammadiyah Purwokerto ${ }^{123}$
}

\begin{abstract}
The research aims to examine the effect of religiosity and demographic factors on investment risk-taking. The demographic factors studied were age, gender, and level of education. This research sample is the owner of SMEs in the Banyumas district, Indonesia. Respondents in this study are 77 Muslim SME owners. The results showed that religiosity and education level had a positive influence on investment risktaking. Age and gender do not influence investment risk-taking. This study will contribute to SME owners, namely the importance of incorporating elements of religion in running their business. This research also contributes to policymakers in developing SMEs in Banyumas Regency, Indonesia.
\end{abstract}

Keywords: Religiosity, Age, Gender, Level of Education, Investment Risk Taking

\section{Introduction}

Human behavior is a missing piece of the puzzle in investment risk-taking research [1]. Decisions about investment and savings are a function of individual risk preferences [2]. Risktaking behavior will have an essential role in individual financial decisions. Risk-taking behavior will be influenced by several factors, such as religion, culture, and demographic factors. This research will raise issues related to religion (religiosity) and risk-taking behavior. Many studies have proven the role of religion in the economic field. Research from [2] proves that the level of Islamic religiosity on the dimensions of virtue and obligation has a significant influence on the allocation of risky assets to the portfolio. Research by [3] shows that a state government with a high level of religiosity will be more careful in issuing its debt policy. Several studies have also proven that the level of religiosity will influence investment risktaking. The level of religiosity will negatively affect investment risk-taking. Several studies have proven this, namely research by [4], [5], [1], [6]. Research on the relationship between religious levels and risk-taking is mostly done in banks or large companies. In contrast, the study has not yet taken a sample in small and medium enterprises (SMEs). Therefore this study provides newness to existing research by examining the relationship between the level of religiosity and risk-taking among SME owners. In this study, the social demographic variables used were age, gender, education. Several studies have shown that social demographic factors influence investment risk-taking. [5], [7] found evidence of age influence on corporate risk-taking. Research [7] also found evidence of gender would influence investment risk-taking. [6], [8] find that education influences risk-taking. This research will be conducted at SME in Banyumas Regency, Central Java, Indonesia. This study will contribute to SME owners, namely the importance of incorporating elements of religion in running their 
business. This research also contributes to policymakers in developing SMEs in Banyumas Regency.

\section{Literature Review}

\subsection{Religiosity and Investment Risk Taking}

Several studies have proven the effect of religiosity on investment risk-taking. Research on the relationship between religious locale and bank risk-taking was conducted by [1]. The study results show that banks with a head office in a country with a high level of religiosity will take lower risks. [6] also conducted research on the relationship between religiosity and risk-taking in banks. The findings show that the religiosity of a bank branch office will be negatively related to the investment risk-taking of the bank.

Research by [8] discusses the influence of local religion on organizational risk-taking behavior using mutual funds. The results of this study prove that religiosity will have a negative influence on investment risk-taking. [9] concluded that in countries where the majority is Muslim and Catholic, religion would negatively affect corporate risk-taking. Whereas the majority of countries are Protestants, religion will have a positive effect on corporate risk-taking.[4] researched the effect of religiosity on the risk of stock price collisions in the capital market. The results showed that companies headquartered in areas with a high level of religiosity would have a risk of low share price collisions. [5] examined the relationship between religion and corporate risk-taking. The researcher uses micro-level data that distinguishes between managerial religiosity, firm intrinsic religiosity, corporate extrinsic religiosity, and social capital. The results of this study found that the manager's religiosity would be negatively related to corporate risk-taking. However, intrinsic religiosity can moderate the relationship. Managers of Islamic companies tend to make risky decisions compared to managers of other companies due to religious, social pressure.

\section{Hypothesis 1: Religiosity influences investment risk-taking}

\subsection{Demographic Factor and Investment Risk Taking}

The results of research on the effect of manager age on risk-taking are still inconsistent. [5] proved that the age of managers had a significant negative effect on debt risk-taking, research, development, and advertising. The effect of the manager's age on investment risk-taking on fixed assets shows a significant positive number. [7] research shows different results. The study found evidence that the manager's age has a significant positive effect on debt investment risk-taking and research and development. The age of the manager has a significant negative effect on advertising investment risk-taking. However, age does not have a significant effect on investment risk in fixed assets. [8] also found the results of research that age does not significantly affect investment risk-taking. [10] prove that age has no significant effect on investment risk-taking. A person's age will not affect the risk-taking of an investment.

\section{Hypothesis 2: Age influences investment risk-taking}


[7] also found the effect of gender on investment risk-taking. The results of his research prove that men dare to bear investment risks. [10] also proved that gender would influence investment risk-taking. Gender has a significant negative effect on investment risk-taking. This shows that men would rather avoid risk than women.

\section{Hypothesis 3: Gender influences investment risk-taking}

[6] provides evidence that the education of managers or company owners will positively influence investment risk-taking. The higher the level of education, the manager will be bolder in taking investment risks. [8] also found the same evidence that owner education will positively influence investment risk-taking. Different results were shown by [10] who found educational outcomes had no significant effect on investment risk-taking.

\section{Hypothesis 4: Level of Education influences investment risk-taking}

\section{Method}

The population of this research is the owner of SMEs in the Banyumas Regency. Based on data from the Department of Industry and SME of Banyumas Regency, the number of SMEs in the Banyumas Regency is 1576 SMEs. The sampling technique used in this study is a purposive sampling technique with the criteria of SMEs registered in the industry service and SMEs of the Banyumas Regency. This study uses multiple linear regression for testing the hypothesis.

Risk-taking uses the measurement of risk tolerance, which is the level of risk where someone feels comfortable or, in other words, a level of risk where investors want to invest. Risk tolerance is assessed by four items that seek answers about clients' willingness to take risks in different scenarios [11]. Items are coded with the lowest value (i.e., 1) for the smallest risk tolerance response and the highest value for most risk tolerances (i.e., 4 or 5 , depending on the number of response options). Zero (0) is coded for the "unsure" option. Questions asked about earnings volatility, investment losses, declining investment values, willingness to bear short-term losses to obtain long-term benefits.

The principle of sharia transactions measures religiosity in this study. This principle is the basic concept of Islamic sharia in running a business. There are five principles, namely, brotherhood, justice, benefit, balance, and universalism. There are 12 question items based on sharia transaction principles. All items were measured using a Likert scale, respondents' answers were given a range from number 1 if the respondent stated strongly disagree to number 5 if the respondent stated strongly agreed. The owner's age is measured by the age of the owner of the SME until the year of the study.

The sex uses a dummy variable, which is 1 for men and 0 for women. Education is measured using the dummy variable number 1 for SME owners who have a high school education and below and 0 for SME owners who have a high school education and above.

\section{Results And Discussion}

Respondents in this study are 77 Muslim SME owners. This study took place in four subdistricts in Banyumas Regency, namely North Purwokerto, East Purwokerto, West 
Purwokerto, and Ajibarang. SMEs have an average number of employees of 2 people. The age of SMEs was established for seven years. The average age of a business owner is 48.5 years. The average SME owner is a high school graduate. The number of male respondents is 36 people, and the number of female respondents is 41 people.

This study uses multiple linear regression to test the hypothesis. The test results of the research data are presented in the table below:

Table 1. Research Result

\begin{tabular}{llll}
\hline \multicolumn{1}{c}{ Variable } & Coefficients & t test & P value \\
\hline Contant & 0,907 & 1,462 & 0,148 \\
Religiosity & 0,273 & 2,254 & $0,027 * *$ \\
Age & 0,00001174 & 0,002 & 0,999 \\
Gender & 0,037 & 0,426 & 0,672 \\
Level of Education & 0,292 & 3,323 & $0,001 * * *$ \\
R2 $20,9 \%$, F stat $=4,757 * * *$ & & \\
\hline \multicolumn{2}{c}{$* *$ significance 1 \% } & & \\
& $* *$ significance 5\%
\end{tabular}

The table above shows the effect of religiosity, age, gender, and education variables on investment risk-taking. The test results show there is a positive influence on the variables of religiosity and education on investment risk-taking. Hypothesis 1 and Hypothesis 4 are supported. In contrast, age and gender do not have a significant effect on investment risktaking. Hypothesis 2 and hypothesis 3 are not supported.

\section{a) Effect of religiosity variable on investment risk-taking}

The variable of religiosity has a positive influence on investment risk-taking. This research provides evidence that the higher the level of religiosity, the more risk-takers will be. These results differ from studies conducted by [4], [6],[8], [9], [12]. The results of this study prove that religiosity has a negative influence on investment risk-taking.

This study's results are in line with the research of [7], which revealed a positive relationship between the founder's religiosity and risk avoidance for adherents of eastern religions. This finding also supports the results of research from [13], which states Muslims tend to have risk-seeking preferences. Research results from [2] about the variable of religiosity based on the dimensions of liability has a positive effect on the tendency to allocate funds to risky assets. [14] revealed that collectively Muslims reject risk. In investing, Islamic investors also consider other factors besides risk, return, and religious issues. These factors include environmental and ethical issues.

\section{b) Effect of age variable on investment risk-taking}

This study found evidence that age had no effect on risk-taking. The results of this study do not support research conducted by [5], [7]. Research [5] shows that age has a negative influence on investment risk-taking. In contrast, research [7] concluded that age has a positive effect on risk-taking.

The results of this study support research conducted by [8], [10], [15], [16]. Age has no significant effect on investment risk-taking. This proves that the older the investor's age will not affect the higher investment risk-taking. 


\section{c) Effect of gender variable on investment risk-taking}

The study found no evidence of gender influencing investment risk-taking. This is different from the results of research by [17], [10], [7], which proves that gender influences investment risk. the results of the study concluded that men preferred risk compared to women. [18] also prove that differences in gender-based behavior can influence company decisions.

This research supports [19], which states that gender does not influence risk. Men and women have no difference in making risky decisions. The results of this study are also in line with previous research, which states that gender does not influence financial behavior [20].

\section{d) Effect of level of education variable on investment risk-taking}

Education level has a positive effect on investment risk-taking. The higher level of education owned by SME owners, the higher the courage to take risks. These results are in line with research conducted by [6], [8]. [21] also states that the level of education has a significant effect on risk tolerance. The results of the study confirm that education patterns that support one's financial background are more likely to be reflected in the form of a high level of willingness to take risks.

\section{Conclusion}

This study provides evidence that religiosity and education level has a positive effect on investment risk-taking. The results of this study contribute to SME owners, namely the importance of incorporating religious elements in running their business. The education level of the SME owner will determine the courage to take risks in developing SMEs. This research also contributes to policymakers in developing SMEs in Banyumas Regency. The government must pay attention to the level of religiosity and education level of SME owners in developing programs related to SMEs.

\section{References}

[1] B. K. Adhikari and A. Agrawal, "Does Local Religiosity Matter for Bank Risk-Taking?," J. Corp. Financ., vol. 38, pp. 272-293, 2016.

[2] N. S. Mahdzan, R. Zainudin, R. Che Hashim, and N. A. Sulaiman, "Islamic Religiosity and Portfolio Allocation: the Malaysian Context," Int. J. Islam. Middle East. Financ. Manag., vol. 10, no. 3, pp. 434-452, 2017.

[3] Y. Chen, Z. Murgulov, S. G. Rhee, and M. Veeraraghavan, "Religious Beliefs and Local Government Financing, Investment, and Cash Holding Decisions," J. Empir. Financ., vol. 38, pp. 258-271, 2016.

[4] J. L. Callen and X. Fang, "Religion and Stock Price Crash Risk," J. Financ. Quant. Anal., vol. 50, no. $1 / 2$, pp. 169-195, 2015.

[5] C. W. H. Cheong, "Religiosity and Corporate Risk-taking," Asian J. Financ. Account., vol. 10, no. 2 , p. 81,2018 .

[6] J. Chircop, M. Fabrizi, E. Ipino, and A. Parbonetti, "Does Branch Religiosity Influence Bank Risk-Taking?,” J. Bus. Financ. Account., vol. 44, no. 1-2, pp. 271-294, 2017.

[7] F. Jiang, Z. Jiang, K. A. Kim, and M. Zhang, "Family-Firm Risk-Taking: Does Religion Matter?," J. Corp. Financ., vol. 33, pp. 260-278, 2015. 
[8] L. Gao, Y. Wang, and J. Zhao, "Does Local Religiosity Affect Organizational Risk-Taking? Evidence From The Hedge Fund Industry," J. Corp. Financ., vol. 47, pp. 1-22, 2017.

[9] J. M. Díez-Esteban, J. B. Farinha, and C. D. García-Gómez, “Are Religion and Culture Relevant for Corporate Risk-Taking? International Evidence," BRQ Bus. Res. Q., 2018.

[10] O. Pak and M. Mahmood, "Impact of Personality on Risk Tolerance and Investment Decisions: A Study on Potential Investors of Kazakhstan," Int. J. Commer. Manag., vol. 25, no. 4, pp. 370$384,2015$.

[11] J. Grable and R. Lytton, "Financial Risk Tolerance Revisited: The Development of a Risk Assessment Instrument," Financ. Serv. Rev., vol. 8, pp. 163-181, 1999.

[12] K. Kanagaretnam, G. J. Lobo, C. Wang, and D. J. Whalen, "Religiosity and Risk-Taking in International Banking," J. Behav. Exp. Financ., vol. 7, pp. 42-59, 2015.

[13] D. Aburish, "Risk, Religion, and Islamic Microfinance Risk," University of San Francisco, 2013.

[14] I. Tahir and M. Brimble, "Islamic Investment Behaviour," Int. J. Islam. Middle East. Financ. Manag., vol. 4, no. 2, pp. 116-130, 2011.

[15] A. Anderson, A. Dreber, and R. Vestman, "Risk Taking, Behavioral Biases and Genes: Results from 149 Active Investors," J. Behav. Exp. Financ., vol. 6, no. 15, pp. 93-100, 2015.

[16] S. N. Khan, "Financial Risk Tolerance: An Analysis of Investor's Cognitive, Decision-Making Styles and Cultural Effects," J. Financ. Account. Manag., vol. 8, no. 1, pp. 20-38, 2017.

[17] L. Farah Margaretha and A. Aprilia, "Study on Financial Risk Towards Individual Investor as Strategy to Improve Urban Community Empowerment," IOP Conf. Ser. Earth Environ. Sci., vol. 106, no. 1, 2018.

[18] A. Palvia, E. Vähämaa, and S. Vähämaa, "Are Female CEOs and Chairwomen More Conservative and Risk Averse? Evidence from the Banking Industry During the Financial Crisis," J. Bus. Ethics, vol. 131, no. 3, pp. 577-594, 2015.

[19] M. N. Sadiq and M. H. Ishaq, "The Effect of Demographic Factors on The Behavior of Investors during The Choice of Investment: Evidence from Twin Cities of Pakistan," Glob. J. Manag. Bus. Res., vol. 14, no. 3, pp. 46-56, 2014.

[20] W. Purwidianti, "An Empirical Study on Family Financial Behavior," in Advances in Social Science, Education and Humanities Research 5th International Conference on Community Development, 2018, November.

[21] A. Shusha, "Does Financial Literacy Moderate the Relationship among Demographic Characteristics and Financial Risk Tolerance? Evidence from Egypt," Australas. Accounting, Bus. Financ. J., vol. 11, no. 3, pp. 67-86, 2017. 